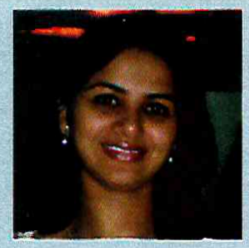

Dr. Ankita Kathpalia

PG student

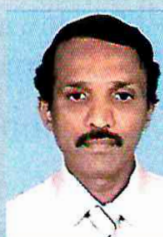

Dr. Dhanyakumar N.M.

Professor \& Head

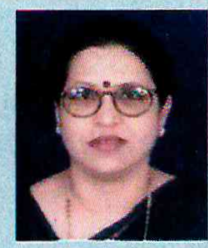

Dr. Vasundhara Shivanna Professor

Department of Conservative Dentistry and Endodontics

\section{What is ETHICS?}

Ethics deals with right conduct. The origin of ethics is derived from the Greek word "ethos" meaning "distinctive character, spirit and attitude of a cultural group". Ethics is defined as the science of morals, of moral principles of right and wrong, specifying rules of right behaviour. Ethics broadly are unwritten laws of profession embodying an expected standard of behaviour. Dental Ethics would mean moral duties and obligations of the dentist towards his patients, professional colleagues and to the society. ${ }^{1,2}$

\section{Values and Norms}

- VALUE is the desirability of a thing, often in respect of some property such as usefulness or exchangeability.eg. treatment to cure, to relieve from pain \& suffering.

- NORM is standard of achievement of behaviour that is required, desired \& designated as normal. eg. Medical help for poor, not practicing for the sake of money.'

\section{Ethical Principles}

There are several principles that health care professionals must be aware of in the practice of their profession. These are:

1. To do no harm (Non-Maleficence)

2. To do good(Beneficence)

3. Respect for persons

4. Justice

5. Veracity or Truthfulness

6. Confidentiality

1. To Do No Harm (Non- Maleficence): It is generally attributed to Hippocrates. It is considered to be the foundation of social morality. Iatrogenic Disease is the name given to doctor induced illness and all of us in dental field have seen overhanging restorations cause periodontal disease or failure to sterilize instruments cause infection.

2. To do good (Beneficence): It should be the role of dentists and dental hygienists to benefit patients, as well as not to inflict harm. The expectation of the patient is that the care provider will initiate beneficial action. All attempts should be to maximize the benefits and minimize harm.

3. Respect for persons : This incorporates at least two other ethical principles. Autonomy dictates that health care professionals respect the patients capacity for self determination in making decision regarding their treatment and Informed consent is an essential component of a patient's right to autonomy.

4. Justice: The primary duty of the health professional is service irrespective of class, creed etc. Justice demands that each person be treated equally. The principle of justice calls for an obligation to protect the weak and to ensure equity in rights and benefits.

5. Veracity or Truthfulness: The patient - doctor relationship is based on trust. Lying to the patient shows disrespect to the patient and threatens relationship.

6. Confidentiality: Every patient has right to expect that all communications and records pertaining to his/her care will be treated as confidential. Earlier it was widely accepted that confidentiality could be breached if it was thought it would benefit the patient.Now patient's permission has to be sought ${ }^{3}$

\section{Codes of conduct}

Ethical codes are important for any profession. It is all more important for the health profession. Ethical code is not legislation, but is equally forceful as it is approved by the profession.

The hippocrates oath: it is adopted as a pattern by medical men throughout ages. In this noble code disciple or graduand is shown responsibility of his calling and it is urged upon him the duty of respect for his school and university, of making freely available any discovery of maintaining professional secrecy and refraining from gossip and taking no advantage of position of medical advisor.'

Modern version of the hippocratic oath " $i$ swear in the presence of the almighty and before my family, my 
teachers and my peers that according to my ability and judgment $i$ will keep this oath and stipulation.

To reckon all who have taught me this art equally dear to me as my parents and in the same spirit and dedication to impart a knowledge of the art of medicine to others. I will continue with diligence to keep abreast of advances in medicine. I will treat without exception all who seek my ministrations, so long as the treatment of others is not compromised thereby, and $\mathrm{i}$ will seek the counsel of particularly skilled physicians where indicated for the benefit of my patient.

I will follow that method of treatment which according to my ability and judgment, i consider for the benefit of my patient and abstain from whatever is harmful or mischievous. I will neither prescribe nor administer a lethal dose of medicine to any patient even if asked nor counsel any such thing nor perform the utmost respect for every human life from fertilization to natural death and reject abortion that deliberately takes a unique human life.

With purity, holiness and beneficence i will pass my life and practice my art. Except for the prudent correction of an imminent danger, $i$ will neither treat any patient nor carry out any research on any human being without the valid informed consent of the subject or the appropriate legal protector thereof, understanding that research must have as its purpose the furtherance of the health of that individual. Into whatever patient setting $i$ enter, $i$ will go for the benefit of the sick and will abstain from every voluntary act of mischief or corruption and further from the seduction of any patient.

Whatever in connection with my professional practice or not in connection with it $i$ may see or hear in the lives of my patients which ought not be spoken abroad, i will not divulge, reckoning that all such should be kept secret.

While i continue to keep this oath unviolated may it be granted to me to enjoy life and the practice of the art and science of medicine with the blessing of the almighty and respected by my peers and society, but should i trespass and violate this oath, may the reverse by my lot." 4

The nuremberg code : the code was enunciated in 1947. The nazi physicians were fined for cruel experiments on prisoners \& those held in concentration camps.the code has given an outlook to sociological, penological \& constitutional values/norms.

Declaration of Helsinki: in 1964 the committee on international organization of medical sciences \& world medical organization formulated it. Giving a code of conduct, it recommends $\&$ guides physician in biomedical research involving human subjects.

International code of medical ethics: in 1963, international code of medical ethics based on who's proposed guidelines was made available. It has given international codes \& universal principles. ${ }^{1}$

\section{Ethical Rules for Dentists- By Dental Council of India:}

The duties and obligations of dentist towards the patients:

1. Every dentist should be courteous, sympathetic, friendly and helpful.

2. He should observe punctuality in fulfilling his appointments.

3. He should establish a well merited reputation for professional ability and fidelity.

4. The welfare of the patient should be conserved to the utmost of the practitioners ability.

5. A dentist should not permit consideration of religion, nationality, race, party politics to intervene between his duties and his patients.

6. Information of a personal nature, which may be learned about or directly from a patient in the course of dental practice, should be kept in utmost confidence.

Duties of Dentist Towards One Another:

1. Every dentist should cherish a proper pride in his/her colleagues and should not disparage them either by act or word.

2. When the dentist is entrusted with the care of the patient of another, during sickness or absence, mutual arrangement should be made regarding remuneration.

3. A dentist called upon in any emergency to treat the patient of another dentist, should when the emergency is provided for, retire in favor of regular or but shall be entitled to charge patient for his services.

4. If a dentist is consulted by the patient of another dentist and the former find that the patient is suffering from previous faulty treatment, it is his duty to institute correct treatment at once with as little comments as possible and in such a manner as to avoid reflection on his predecessor.

Duties of the Dentist to the Public: Police and Law Courts

1. A dentist is not bound to disclose professional secrets unless called upon by the magistrate or judge to do so.

2. Knowledge of a patient gained in the course of examination and treatment is privileged and should not be disclosed without the consent of the patient or an order from the presiding judge in a court of law. ${ }^{3}$

\section{Research Ethics}

It denotes an area of faithful discrimination of doing right/wrong in professional activities. The research may 
be individual study/ group study/ comparative study where codes of conduct are laid upon which form the basis for RESEARCH ETHICS. These codes for research ethics are applied for : Animal and Experimental Research, Human experimentation, Human Volunteer Research and for drug trials. ${ }^{2}$

\section{Some Unethical Practices in Dentistry}

1. Practice by unregistered persons employed by the dentist.

2. Dentist signed under his name \& authority issuing any certificate that is untrue, misleading or improper.

3. Dentist advertising directly or indirectly for obtaining patients or obtaining his own professional advantage.

4. Use of bogus diplomas etc.

5. Allowing Commission.

6. Advertising/ peddling of services provided in clinic.

7. Undercutting of charges in order to solicit patients.

8. If the planned treatment is beyond the dentist's skills $\&$ patient is not referred to consultant.

9. If consulted, dentist accepts the charge of case without request of referring dentist.

10. In case of an emergency consultation, during temporary absence of patient's dentist, temporary service is provided \& patient is not sent back.

11. Illegal Practice by others is aided. ${ }^{3}$

\section{Conclusion}

Ethics may be considered as the hills of help for modern man for, the more he studies ethics \& the more he uses ethical concepts as guides, the more he is strengthened in character. "ETHICS WARMS THE HEART AND COOLS THE MIND"

\section{References}

1. C M Francis. Medical Ethics. New Delhi. Jaypee Brothers Medical Publishers PvtLtd: 1993

2. G.N. Prabhakaran. A Short Textbook of Professional Medical Ethics. Ed. First. Hyderabad. Paras Publishing:2001.

3. Soben Peter.Essentials of Preventive \& community Dentistry. 3rd edition. New Delhi.Arya (medi) Publishers: May 2003

4. http://nktiuro.tripod.com/hippocra.htm 16.01.2012

5. George M. Gluck, Warren M. Morganstein .Jong's Community Dental Health .Ed. $4^{\text {th }} .1999$.

6. Gilbier S, Wright D, Bishop M. Ethics and Dentistry: The meaning of ethics. Dent Update 2001;28:468-73. 